CARPATHIAN JOURNAL OF FOOD SCIENCE AND TECHNOLOGY

journal homepage, http://chimie-biologie.ubm.ro/carpathian_journal/index.html

\title{
EFFECT OF PRETREATMENTS AND DRYING METHODS ON PHYSICOCHEMICAL PROPERTIES OF UNRIPE PLANTAIN FLOUR AND SENSORY ACCEPTABILITY OF ITS COOKED DOUGH $(A M A L A)$
}

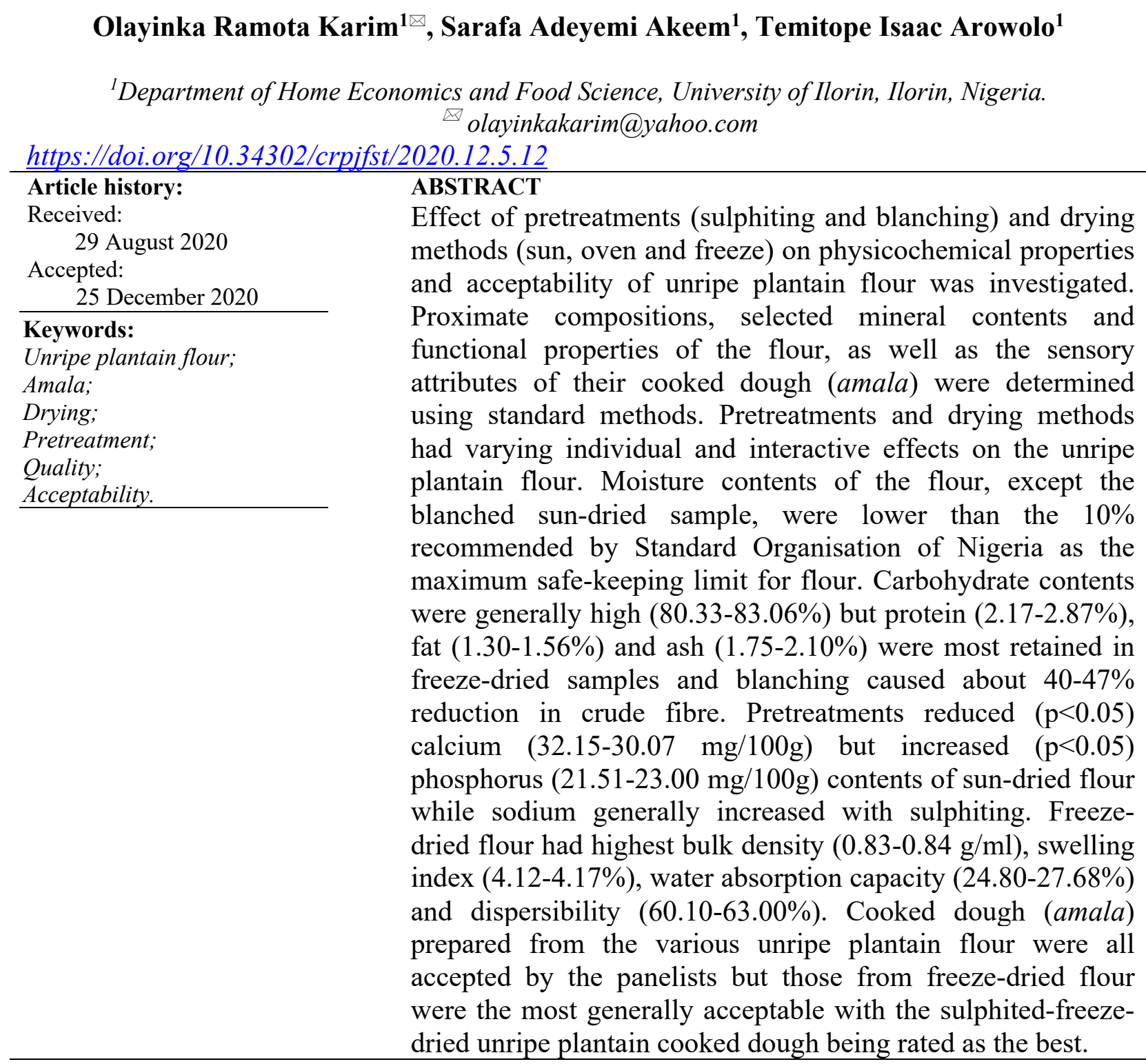

\section{Introduction}

Plantain (Musa paradisiaca) is a perennial tree crop which belongs to the kingdom Plantae and the family Musaceae. It is attractive to farmers due to its low requirement of labour and agricultural input for production (Marriott and Lancester, 1983) and has been reported to contribute to subsistence economies in Africa. Production of plantain in Nigeria was reported to have doubled within two decades before 2010 and the fruit was ranked third among 
starchy staples (Akinyemi et al., 2010), serving as a source of carbohydrates for millions of people in the country. Plantain is low in fat and protein but rich in essential minerals (Karim et al., 2015).

The African landrace, "Agbagba", at the green stage, has a moisture content of about $61 \%$ (on wet basis), which increases during ripening to about $68 \%$ due to carbohydrate hydrolysis (Adeniji et al., 2006). The high moisture content of plantain makes it a perishable fruit. In Nigeria, for instance, quite a fraction of over $80 \%$ of plantain harvested during the peak period between September and February goes into a waste (Ogazi, 1996). This limits off-season availability of the fruit and, in particular, its use by urban populations. As noted by Karim (2005) for fruits and vegetables, one of the most difficult aspects of plantain production is the maintenance of its freshness as there is a physiological deterioration during storage resulting to a significant loss of nutritional value and in many cases, loss of the whole fruits. This phenomenon is usually worse with stored ripe fruits. Unripe plantain on the other hand has a relatively longer shelf life and a more stable physical and nutritional quality. In addition, it offers some health benefits such as reduction of blood sugar level owing to its rich content of dietary fibre $(8.20 \%)$ and resistant starch $(16.20 \%)$ as well as essential micronutrients (Chinma et al., 2012).

A technique to further extend the shelf life and utilization of unripe plantain is the processing of the fruit into flour which can then be stirred in appropriate quantity of boiling water to form gel (amala) and eaten with vegetable soup or any other soup of one's choice. Processing into flour adds value to plantain for both local market and export purposes (Zakpaa et al., 2010; Falade and Ogunwolu, 2012) while also helping to curtail glut (Ogundare-Akanmu, et al., 2012). Drying prior to milling into flour significantly extends the shelf life of a food material as moisture content and water activity will have greatly reduced. Different methods of drying including cabinet, solar, sun, oven, microwave oven, foam-mat, fluidized bed, tray and freeze drying have been reported to influence the physical, chemical, functional and nutritional qualities of unripe plantain flour (Emperatríz et al., 2008; Falade and Olugbuyi, 2010; Falade and Oyeyinka, 2015; Yarkwan and Uvir, 2015; Arinola et al., 2016; Fadimu et al., 2018a; Ndayambaje et al., 2019). This is associated with different rate and pattern of heat and mass transfer, due to different structural make-up of the material being dried (Karim, 2010). Although most of these authors employed a single or combined pretreatments among sulphiting, osmotic dehydration and blanching to control the plantain products' qualities, the influence of pretreatments, singly or in combination with different drying methods was not distinctively elucidated.

Enzymatic browning reaction, attributable to the activity of polyphenol oxidase (tyrosinase) (Carbonaro and Mattera, 2002) which often influences the appearance of food materials, is one of the challenges faced during the processing of plantain. This makes pretreatment an essential part of plantain processing operation. Based on this, Fadimu et al. (2018b) have researched and reported blanching temperature of $50{ }^{\circ} \mathrm{C}$, a blanching time of $6.447 \mathrm{~min}$ and $1 \%$ potassium metabisulphite to be the optimum pre-treatment conditions for unripe plantain based on the functional properties and proximate composition of the unripe plantain flour. However, the effectiveness of pretreatments, singly in arresting enzymatic browning and other undesirable changes and in combination with different drying methods to produce high quality and acceptable plantain products is worth given special consideration. Therefore, this study aimed at investigating the effect of different pretreatments (sulphiting and blanching) and drying methods (sun, oven and freeze) on the physicochemical properties of unripe plantain flour and sensory acceptability of its cooked dough (amala). 


\section{Materials and methods}

\subsection{Materials}

Mature unripe plantains (Agbagba) used for this study were obtained from Ganmo market, Ilorin, Kwara State. The plantains were of stage 1 maturity with acceptable quality for consumption.

\subsection{Experimental Design}

A two-factorial design adopted for this study was from three levels of pretreatments (control, sulphiting and blanching) and three drying methods (sun, oven and freeze-drying). There were 3 controls (no pretreatment), resulting to nine $(3 \times 3)$ treatments (Table 1$)$.

\subsection{Pretreatments}

The unripe plantains were cleaned, peeled, washed and manually sliced (approximately 2 $\mathrm{mm}$ thickness). The sliced plantains were divided into three batches. Two batches each containing $5 \mathrm{~kg}$ of plantain slices were subjected to different pretreatments. One batch was dipped in 1,500 ppm sodium metabisulphite $\left(\mathrm{Na}_{2} \mathrm{~S}_{2} \mathrm{O}_{5}\right)$ solution for $2 \mathrm{~min}$, while the other was placed in a plastic drainer and then immersed in hot $\left(70{ }^{\circ} \mathrm{C}\right)$ water for 2 min. Both were adequately drained on wire mesh. The third batch of the sliced plantain was used as the control (without pretreatment).

\subsection{Drying of Pretreated Unripe Plantain Flour}

\subsubsection{Freeze Drying}

Each of the batches of pretreated unripe plantain slices and the batch without pretreatment were spread out in layers of about $1 \mathrm{~cm}$ thickness in a separate tray-drying accessory at $-18{ }^{0} \mathrm{C}$ for $24 \mathrm{hrs}$ and then lyophilized using a Freezone 4.5 lyophilizer (Labconco; Missouri, USA) for $5 \mathrm{hrs}$ as described by Emperatríz et al. (2008). The resulting dried unripe plantain slices were milled into flour, packed and sealed inside hermetic plastic containers and stored in a cool dry place for further analyses.

\subsubsection{Oven Drying}

Pretreated unripe plantain slices and the ones without pretreatment were dried in an air draft oven (Gallenkamp 300 plus series, England) at $70^{\circ} \mathrm{C}$ for $10 \mathrm{hrs}$ (Chinma et al., 2012). These were then milled into flour and subsequently handled as described for freezedried samples.

\subsubsection{Sun Drying}

Another batch of unripe plantain slices (with and without pretreatments) were thinly spread out on trays and placed in the sun between 10:00 am and 4:30 pm (Agoreyo et al, 2011) for 3 days at $35 \pm 2{ }^{0} \mathrm{C}$ after which they were milled into flour, packaged and stored as described for freeze-dried samples.

\subsection{Determination of Chemical Properties of Unripe Plantain Flour}

The proximate compositions including moisture, crude protein, crude fat, crude fibre and ash were determined following the methods of AOAC (2005). Carbohydrates were determined by difference. Mineral contents such as calcium, iron and sodium, were determined using Atomic Absorption Spectroscopic method while colorimetric method involving the use of ammonium vanadate reaction was adopted for phosphorus determination (James, 1995).

\subsection{Determination of Functional Properties of Unripe Plantain Flour}

Bulk density, swelling index and water absorption capacity of the unripe plantain flour were determined following the methods described by Zakpaa et al. (2010) while the method described by Ohizua et al. (2017) was used to determine dispersibility of the flour in water.

\subsection{Preparation of Unripe Plantain Cooked Dough (Amala)}

Cooked stiff dough (amala) was prepared following the procedures described by Karim et al. (2013). Briefly, unripe plantain flour was gently and gradually poured into boiling water with continuous stirring using a wooden stirrer until a homogenous paste was formed. The 
paste was covered and left on the heat source for about 5 min to cook. It was further stirred before being wrapped in polythene nylon and kept in a food warmer for subsequent sensory analysis.

\subsection{Sensory Evaluation of Unripe Plantain Cooked Dough (Amala)}

Fifty (50) panellists, comprising staff and students who are conversant with the quality attributes of amala made from yam flour, were drawn from the Department of Home Economics and Food Science, University of Ilorin. They were requested to assess the colour, aroma, mouldability and overall acceptability of the coded unripe plantain amala samples using a 9-point hedonic preference scale ranging from 1 (dislike extremely) to 9 (like extremely).

\subsection{Statistical Analysis}

Results of the various analyses were subjected to analysis of variance (ANOVA) using Statistical Package for Social Science (SPSS, version 16.0) and means generated were separated using Duncan multiple range test $(\mathrm{p}<$ $0.05)$.

\section{Results and discussion}

\subsection{Proximate Composition of Unripe Plantain Flour}

Results show that the various drying and pretreatment methods had significant $(p<0.05)$ effects on the moisture content of unripe plantain flour (Table 2). For each of the pretreated and control (without pretreatment) set of samples, freeze-dried plantain flour recorded the lowest moisture contents (7.36$9.29 \%$ ). The highest rate of moisture removal by freeze-drying obtained in this study is similar to the finding of Emperatríz et al. (2008) and Shofian et al. (2011) who reported lower moisture contents with freeze-drying than any other methods of drying studied. The range of moisture contents of the various plantain flour, except for the blanched sundried sample, was below the level (10\%) recommended by Standard Organisation of Nigeria (SON) for safe keeping quality of flour (Chinma et al., 2012). Moisture content is an important indication of product quality stability. Unripe plantain flour without pretreatment were higher $(4.07-4.13 \%)$ in crude fibre than the sulphited (3.20-3.85\%) and blanched (2.13-2.46\%) samples. Drying methods brought about no significant difference in crude fibre contents of the unripe plantain flour without pretreatment. Emperatríz et al. (2008) and Gwanfogbe et al. (1988) observed that dehydration methods had no significant effect on the dietary fibre of flour. However, the effect of drying methods appeared to be enhanced by the pretreatments with blanching exhibiting most effect and reducing the crude fibre content by about $40 \%$ in freeze-dried and $47 \%$ in oven-dried samples. In their report, Arisa et al. (2013) recorded $35 \%$ reduction in the crude fibre content of blanched plantain flour. This suggests that alteration of food tissues through pretreatment breaks down some of the components, such as resistant starch, that may have rather been present as fibre constituent. The range of values obtained in this study are however similar to the range of $2.28-4.44 \%$ reported by Arisa et al. (2013) and $2.56-3.21 \%$ reported by Fadimu et al. (2018a). Crude fibre, which is a type of dietary fibre remaining after food has been subjected to acid and alkali treatments, has useful biological functions such as aiding of digestion and diabetes management (Anderson et al., 2009).

The protein content of the unripe plantain flour without pretreatment was significantly ( $p$ $<0.05$ ) higher with freeze-drying than sun and oven drying methods. Since the reverse was recorded in moisture contents, the apparent effect of drying methods on protein content may actually be an indirect effect of reduced moisture, bringing about different levels of concentrated proteins in the flour samples. Generally, sulphiting had a more significant increase on the protein proportion of unripe plantain flour than did blanching. Though the range of protein contents recorded in this study 
for unripe plantain flour was generally low $(2.17-2.87 \%)$, it was not unexpected since unripe plantain flour is typically poor in protein supply (Zakpaa et al., 2010; Karim et al. 2015; Fadimu et al. 2018a). Besides, the cooked dough (amala) is commonly eaten alongside soup prepared with meat or any other source of protein such as soycheese (meat analog). Another strategy to compensate for the low protein content is fortification of the flour with a protein rich material such as soyflour.

Pretreatment methods did not show a particularly defined significant effect on the fat contents of the unripe plantain flour but freezedried samples generally had the highest range of fat contents $(1.45-1.56 \%)$ while the ovendried samples had the lowest (1.35-1.36\%). A similar finding was reported by Emperatríz et al. (2008) that freeze-dried and oven-dried unripe plantain flour had highest and lowest fat contents, respectively. Freeze-dried unripe plantain flour recorded the highest ash contents (1.97-2.10\%), significantly varied with pretreatment methods, while sun-dried samples recorded the lowest $(1.75-1.79 \%)$ but did not show any significant response to pretreatment differences (Table 2). The ash contents obtained in this study were similar to those (1.98-2.30\%) reported by Emperatríz et al. (2008). Ash content represents the amount of minerals in food stuff.

The carbohydrate content of the unripe plantain flour ranged from $80.33-83.06 \%$ with blanched samples having the highest values while the samples without pretreatment (control) had the lowest. This again is suggestive of the possibility that as pretreatment alters the tissue matrix of food materials, more carbohydrate constituents may have been made more available for chemical analysis, which by extension, could be indicative of a digestive advantage. A similar effect of pretreatment on the carbohydrate content of plantain flour was observed by Arisa et al. (2013). Carbohydrate rich foods supply energy to the body more readily than any other energy source, and energy supply is the main contribution of plantain to diet (Zakpaa et al., 2010).

\subsection{Mineral Content of Unripe Plantain Flour}

Calcium and phosphorus were more predominant in the unripe plantain flour than iron and sodium (Table 3). Sulphiting had a significant $(p<0.05)$ effect, increasing the sodium content of the unripe plantain flour. This could be attributed to sodium up-take from sodium metabisulphite solution used as one of the pretreatments. Blanching and sulphiting had significant $(p<0.05)$ effect on sun-dried unripe plantain flour, both causing decreased in calcium and increased in phosphorus contents. Freeze-dried samples were generally significantly $(\mathrm{p}<0.05)$ higher in iron content than their sun-dried counterparts. The sodium contents (2.07-2.39\%), though a bit higher than the range of values $(0.52-1.05 \%)$ reported by Arisa et al. (2013) for pretreated plantain flour, were generally low, and this could be recommended for a low-sodium diet (Ojure and Quadri, 2012). It can be used in the management of high blood pressure and heart disease (Dzomeku et al., 2007) The findings of Ojure and Quadri (2012) support the relatively higher amount of calcium obtained in this study for unripe plantain flour. The authors reported a value as high as $71.5 \mathrm{mg} / 100 \mathrm{~g}$ in the variety of plantain studied.

\subsection{Functional Properties of the Unripe Plantain Flour}

Generally, the bulk densities of freeze-dried unripe plantain flour $(0.83-0.84 \mathrm{~g} / \mathrm{ml})$ were higher than those of oven and sun-dried samples (0.76-0.81 g/ml and 0.79-0.82 g/ml, respectively), but drying methods had no individual significant effect (Table 4). Blanching was the only pretreatment that appeared to have singly reduced bulk density significantly $(p<0.05)$ and this was just in oven-dried unripe plantain flour (i.e., between oven-dried blanched and oven-dried unblanched samples). This was similar to the finding of Arisa et al. (2013) who reported that 
blanched plantain flour had significantly lower bulk density than sulphited plantain flour and control (without pretreatment). Zakpaa et al. (2010) reported a slightly lower value $(0.755$ $\mathrm{g} / \mathrm{ml}$ ) for ripe plantain flour. Bulk density is an important factor for bulk storage and transportation.

Similarly, freeze-dried unripe plantain flour showed the highest swelling indices (4.12$4.17 \%$ ) while oven-dried samples recorded the lowest range of value of 3.11-3.25\%. Drying and pretreatment methods had both individual and interactive significant $(\mathrm{p}<0.05)$ effects on the swelling indices of unripe plantain flour, with blanching causing most increase in swelling indices. Freeze-dried plantain flour had better swelling indices probably due to the destructive effect of other drying methods on the starch components of the plantain (Olawuni et al., 2013). Swelling index is an indication of the absorption index of the starch granules during heating.

Methods of drying showed a significant ( $p$ $<0.05$ ) effect on the water absorption capacity of unripe plantain flour without pretreatment, with freeze-dried and oven-dried controls having $27.68 \%$ and $25.31 \%$, respectively. Pretreatments methods had significant $(\mathrm{p}<$ 0.05 ) effect on water absorption capacity of the unripe plantain flour, except in oven-dried samples. The unripe plantain flour that were not pretreated showed significant $(p<0.05)$ differences in dispersibility with drying methods. The dispersibility of the flour which ranged between $60.10 \%$ and $63.00 \%$ was higher than $52.00-56.00 \%$ reported for unblanched cooking banana and sweet potato flour, respectively, by Ohizua et al. (2017). This means that the unripe plantain flour will be relatively easier to reconstitute in the making of consistent cooked dough (amala).

\subsection{Sensory Quality of Pretreated Sun, Oven and Freeze-Dried Unripe Plantain Cooked Dough (Amala)}

Table 1. Factorial design for the study

\begin{tabular}{|l|l|l|l|}
\hline Pretreatment & Control (No pretreatment) & Sulphiting & Blanching \\
\hline Drying method & Oven drying & Sun drying & Freeze drying \\
\hline
\end{tabular}

Table 2. Proximate composition of pretreated sun, oven and freeze-dried plantain flour

\begin{tabular}{|c|c|c|c|c|c|c|}
\hline Sample & $\begin{array}{l}\text { Moisture } \\
\text { (\%) }\end{array}$ & $\begin{array}{l}\text { Crude } \\
\text { Protein (\%) }\end{array}$ & Fat $(\%)$ & Ash (\%) & $\begin{array}{l}\text { Crude fibre } \\
(\%)\end{array}$ & $\begin{array}{l}\text { Carbohydrate } \\
\text { (\%) }\end{array}$ \\
\hline $\mathbf{N S}_{\mathbf{U}}$ & $9.19 \pm 0.09^{\mathrm{bcd}}$ & $2.30 \pm 0.04^{\mathrm{fg}}$ & $1.30 \pm 0.01^{\mathrm{ef}}$ & $1.75 \pm 0.01^{\mathrm{e}}$ & $4.10 \pm 0.09^{\mathrm{a}}$ & $81.36 \pm 0.05^{\mathrm{ab}}$ \\
\hline $\mathbf{B S}_{\mathbf{U}}$ & $10.11 \pm 0.05^{\mathrm{a}}$ & $2.36 \pm 0.15^{\mathrm{ef}}$ & $1.44 \pm 0.04^{\mathrm{bcd}}$ & $1.77 \pm 0.01^{\mathrm{e}}$ & $2.42 \pm 0.01^{\mathrm{e}}$ & $81.90 \pm 0.03^{\mathrm{a}}$ \\
\hline $\mathbf{S S}_{\mathbf{U}}$ & $9.80 \pm 0.02^{\mathrm{bc}}$ & $2.61 \pm 0.01^{\mathrm{cd}}$ & $1.45 \pm 0.03^{\mathrm{bc}}$ & $1.79 \pm 0.01^{\mathrm{e}}$ & $3.64 \pm 0.04^{\mathrm{bc}}$ & $80.71 \pm 0.00^{\mathrm{b}}$ \\
\hline $\mathrm{NO}_{\mathrm{v}}$ & $8.15 \pm 0.02^{\mathrm{de}}$ & $2.17 \pm 0.03^{\mathrm{g}}$ & $1.36 \pm 0.03^{\mathrm{de}}$ & $1.87 \pm 0.02^{\mathrm{d}}$ & $4.07 \pm 0.05^{\mathrm{a}}$ & $82.38 \pm 0.14^{\mathrm{a}}$ \\
\hline $\mathbf{B O}_{\mathrm{v}}$ & $8.74 \pm 0.05^{\text {bcde }}$ & $2.65 \pm 0.03^{\mathrm{bc}}$ & $1.38 \pm 0.03^{\text {cde }}$ & $2.04 \pm 0.03^{b}$ & $2.13 \pm 0.02^{\mathrm{f}}$ & $83.06 \pm 0.06^{\mathrm{a}}$ \\
\hline $\mathbf{S O}_{\mathrm{V}}$ & $9.53 \pm 0.01^{\text {bcd }}$ & $2.63 \pm 0.02^{\mathrm{cd}}$ & $1.35 \pm 0.01^{\mathrm{ef}}$ & $2.04 \pm 0.02^{\mathrm{b}}$ & $3.20 \pm 0.01^{\mathrm{d}}$ & $81.25 \pm 0.08^{\mathrm{ab}}$ \\
\hline $\mathbf{N F}_{\mathrm{R}}$ & $7.36 \pm 0.03^{\mathrm{e}}$ & $2.67 \pm 0.04^{\mathrm{bc}}$ & $1.45 \pm 0.04^{\mathrm{bcd}}$ & $1.97 \pm 0.01^{\mathrm{c}}$ & $4.13 \pm 0.08^{\mathrm{a}}$ & $82.42 \pm 0.08^{\mathrm{a}}$ \\
\hline $\mathbf{B F}_{\mathrm{R}}$ & $8.46 \pm 0.04^{\text {cde }}$ & $2.84 \pm 0.01^{\mathrm{ab}}$ & $1.53 \pm 0.01^{\mathrm{ab}}$ & $2.04 \pm 0.01^{\mathrm{b}}$ & $2.46 \pm 0.01^{\mathrm{e}}$ & $82.67 \pm 0.03^{\mathrm{a}}$ \\
\hline $\mathbf{S F}_{\mathrm{R}}$ & $9.29 \pm 0.01^{\mathrm{bcd}}$ & $2.87 \pm 0.0^{\mathrm{a}}$ & $1.56 \pm 0.01^{\mathrm{a}}$ & $2.10 \pm 0.01^{\mathrm{a}}$ & $3.85 \pm 0.01^{b}$ & $80.33 \pm 0.07^{\mathrm{b}}$ \\
\hline
\end{tabular}

Data are reported as mean \pm standard deviation of triplicate determinations. Mean scores within the same column with different superscripts are significantly $(\mathrm{p}<0.05)$ different.

$\mathrm{NS}_{\mathrm{U}}=$ Non-pretreated sun-dried unripe plantain flour

$\mathrm{BS}_{\mathrm{U}}=$ Blanched sun-dried unripe plantain flour

$\mathrm{SS}_{\mathrm{U}}=$ Sulphited sun-dried unripe plantain flour

$\mathrm{NO}_{\mathrm{v}}=$ Non-pretreated oven-dried unripe plantain flour 
$\mathrm{BO}_{\mathrm{V}}=$ Blanched oven-dried unripe plantain flour

$\mathrm{SO}_{\mathrm{V}}=$ Sulphited sun-dried unripe plantain flour

$\mathrm{NF}_{\mathrm{R}}=$ Non-pretreated freeze-dried unripe plantain flour

$\mathrm{BF}_{\mathrm{R}}=$ Blanched freeze-dried unripe plantain flour

$\mathrm{SF}_{\mathrm{R}}=$ Sulphited freeze-dried unripe plantain flour

Table 3. Mineral contents of pretreated sun, oven and freeze-dried unripe plantain flour

\begin{tabular}{|c|c|c|c|c|}
\hline Samples & $\begin{array}{l}\text { Calcium } \\
(\mathrm{mg} / 100 \mathrm{~g})\end{array}$ & Phosphorus (mg/100g) & $\begin{array}{l}\text { Iron } \\
(\mathrm{mg} / 100 \mathrm{~g})\end{array}$ & Sodium $(\mathrm{mg} / 100 \mathrm{~g})$ \\
\hline $\mathrm{RP}$ & $29.31 \pm 0.02^{\mathrm{d}}$ & $21.47 \pm 0.06^{\mathrm{e}}$ & $2.28 \pm 0.04^{\mathrm{c}}$ & $2.07 \pm 0.02^{\mathrm{d}}$ \\
\hline $\mathrm{NS}_{\mathrm{U}}$ & $32.15 \pm 0.05^{\mathrm{a}}$ & $21.51 \pm 0.03^{\mathrm{e}}$ & $2.30 \pm 0.03^{c}$ & $2.13 \pm 0.02^{\mathrm{c}}$ \\
\hline $\mathrm{BS}_{\mathrm{U}}$ & $30.69 \pm 0.03^{b c}$ & $22.63 \pm 0.01^{\mathrm{d}}$ & $2.33 \pm 0.05^{\mathrm{c}}$ & $2.19 \pm 0.01^{\mathrm{c}}$ \\
\hline $\mathrm{SS}_{\mathrm{U}}$ & $30.07 \pm 0.01^{\mathrm{c}}$ & $23.00 \pm 0.04^{\mathrm{c}}$ & $2.35 \pm 0.01^{\mathrm{c}}$ & $2.27 \pm 0.04^{\mathrm{bc}}$ \\
\hline $\mathrm{NO}_{\mathrm{V}}$ & $31.74 \pm 0.05^{\mathrm{a}}$ & $23.14 \pm 0.05^{\mathrm{c}}$ & $2.39 \pm 0.01^{\mathrm{bc}}$ & $2.39 \pm 0.01^{\mathrm{bc}}$ \\
\hline $\mathrm{BO}_{\mathrm{V}}$ & $31.39 \pm 0.08^{\mathrm{ab}}$ & $23.63 \pm 0.02^{\mathrm{bc}}$ & $2.42 \pm 0.02^{\mathrm{b}}$ & $2.18 \pm 0.07^{\mathrm{c}}$ \\
\hline $\mathrm{SO}_{\mathrm{V}}$ & $31.43 \pm 0.02^{\mathrm{ab}}$ & $24.03 \pm 0.02^{\mathrm{ab}}$ & $2.44 \pm 0.03^{\mathrm{ab}}$ & $2.29 \pm 0.03^{b}$ \\
\hline $\mathrm{NF}_{\mathrm{R}}$ & $29.97 \pm 0.06^{\mathrm{c}}$ & $23.92 \pm 0.01^{\mathrm{ab}}$ & $2.47 \pm 0.03^{\mathrm{a}}$ & $2.09 \pm 0.01^{\mathrm{d}}$ \\
\hline $\mathrm{BF}_{\mathrm{R}}$ & $29.72 \pm 0.02^{\mathrm{cd}}$ & $24.80 \pm 0.01^{\mathrm{a}}$ & $2.48 \pm 0.02^{\mathrm{a}}$ & $2.14 \pm 0.01^{\mathrm{c}}$ \\
\hline $\mathrm{SF}_{\mathrm{R}}$ & $29.84 \pm 0.01^{\mathrm{cd}}$ & $25.31 \pm 0.03^{a}$ & $2.46 \pm 0.01^{\mathrm{a}}$ & $2.38 \pm 0.05^{\mathrm{a}}$ \\
\hline
\end{tabular}

Data are reported as mean \pm standard deviation of triplicate determinations. Mean scores within the same column with different superscripts are significantly $(\mathrm{p}<0.05)$ different.

$\mathrm{RP}=$ Ripe plantain flour

$\mathrm{NS}_{\mathrm{U}}=$ Non-pretreated sun-dried unripe plantain flour

$\mathrm{BS}_{\mathrm{U}}=$ Blanched sun-dried unripe plantain flour

$\mathrm{SS}_{\mathrm{U}}=$ Sulphited sun-dried unripe plantain flour

$\mathrm{NO}_{\mathrm{v}}=$ Non-pretreated oven-dried unripe plantain flour

$\mathrm{BO}_{\mathrm{V}}=$ Blanched oven-dried unripe plantain flour

$\mathrm{SO}_{\mathrm{V}}=$ Sulphited sun-dried unripe plantain flour

$\mathrm{NF}_{\mathrm{R}}=$ Non-pretreated freeze-dried unripe plantain flour

$\mathrm{BF}_{\mathrm{R}}=$ Blanched freeze-dried unripe plantain flour

$\mathrm{SF}_{\mathrm{R}}=$ Sulphited freeze-dried unripe plantain flour

Table 4. Functional properties of pretreated sun, oven and freeze-dried unripe plantain flour

\begin{tabular}{|l|c|c|c|c|}
\hline \multicolumn{1}{|c|}{ Samples } & $\begin{array}{c}\text { Bulk density } \\
(\mathbf{g} / \mathbf{m l})\end{array}$ & $\begin{array}{c}\text { Swelling power } \\
\mathbf{( \% )}\end{array}$ & $\begin{array}{c}\text { Water absorption } \\
\text { capacity (\%) }\end{array}$ & $\begin{array}{c}\text { Dispersibility } \\
(\mathbf{\%})\end{array}$ \\
\hline $\mathbf{N S}_{\mathbf{U}}$ & $0.82 \pm 0.01^{\mathrm{ab}}$ & $3.05 \pm 0.01^{\mathrm{h}}$ & $26.41 \pm 0.01^{\mathrm{b}}$ & $62.36 \pm 0.04^{\mathrm{c}}$ \\
\hline $\mathbf{B S}_{\mathbf{U}}$ & $0.79 \pm 0.01^{\mathrm{b}}$ & $3.29 \pm 0.01^{\mathrm{d}}$ & $25.50 \pm 0.04^{\mathrm{d}}$ & $61.03 \pm 0.02^{\mathrm{f}}$ \\
\hline $\mathbf{S S}_{\mathbf{U}}$ & $0.81 \pm 0.01^{\mathrm{ab}}$ & $3.10 \pm 0.01^{\mathrm{g}}$ & $25.01 \pm 0.01^{\mathrm{c}}$ & $62.63 \pm 0.03^{\mathrm{b}}$ \\
\hline $\mathbf{N O}_{\mathbf{V}}$ & $0.79 \pm 0.02^{\mathrm{b}}$ & $3.11 \pm 0.01^{\mathrm{g}}$ & $25.31 \pm 0.01^{\mathrm{cd}}$ & $61.94 \pm 0.01^{\mathrm{d}}$ \\
\hline $\mathbf{B O}_{\mathbf{V}}$ & $0.76 \pm 0.01^{\mathrm{c}}$ & $3.25 \pm 0.01^{\mathrm{e}}$ & $25.00 \pm 0.01^{\mathrm{cd}}$ & $62.02 \pm 0.04^{\mathrm{d}}$ \\
\hline $\mathbf{S O}_{\mathbf{V}}$ & $0.81 \pm 0.01^{\mathrm{ab}}$ & $3.13 \pm 0.01^{\mathrm{f}}$ & $25.52 \pm 0.01^{\mathrm{cd}}$ & $61.98 \pm 0.01^{\mathrm{d}}$ \\
\hline $\mathbf{N F}_{\mathbf{R}}$ & $0.83 \pm 0.02^{\mathrm{ab}}$ & $4.12 \pm 0.01^{\mathrm{c}}$ & $27.68 \pm 0.02^{\mathrm{a}}$ & $60.10 \pm 0.14^{\mathrm{g}}$ \\
\hline $\mathbf{B F}_{\mathbf{R}}$ & $0.83 \pm 0.01^{\mathrm{a}}$ & $4.31 \pm 0.01^{\mathrm{a}}$ & $26.92 \pm 0.02^{\mathrm{b}}$ & $61.64 \pm 0.02^{\mathrm{e}}$ \\
\hline $\mathbf{S F}_{\mathbf{R}}$ & $0.84 \pm 0.02^{\mathrm{a}}$ & $4.17 \pm 0.01^{\mathrm{b}}$ & $24.80 \pm 0.01^{\mathrm{d}}$ & $63.00 \pm 0.14^{\mathrm{a}}$ \\
\hline
\end{tabular}

Data are reported as mean \pm standard deviation of triplicate determinations. Mean scores within the same column with different superscripts are significantly $(\mathrm{p}<0.05)$ different.

$\mathrm{NS}_{\mathrm{U}}=$ Non-pretreated sun-dried unripe plantain flour

$\mathrm{BS}_{\mathrm{U}}=$ Blanched sun-dried unripe plantain flour 
$\mathrm{SS}_{\mathrm{U}}=$ Sulphited sun-dried unripe plantain flour

$\mathrm{NO}_{\mathrm{v}}=$ Non-pretreated oven-dried unripe plantain flour

$\mathrm{BO}_{\mathrm{v}}=$ Blanched oven-dried unripe plantain flour

$\mathrm{SO}_{\mathrm{V}}=$ Sulphited sun-dried unripe plantain flour

$\mathrm{NF}_{\mathrm{R}}=$ Non-pretreated freeze-dried unripe plantain flour

$\mathrm{BF}_{\mathrm{R}}=$ Blanched freeze-dried unripe plantain flour

$\mathrm{SF}_{\mathrm{R}}=$ Sulphited freeze-dried unripe plantain flour

Table 5. Sensory attributes of pretreated sun, oven and freeze-dried unripe plantain cooked dough

(amala)

\begin{tabular}{|l|l|l|l|l|}
\hline Samples & Colour & Aroma & Texture & $\begin{array}{l}\text { General } \\
\text { Acceptability }\end{array}$ \\
\hline $\mathrm{NS}_{\mathrm{U}}$ & $4.80 \pm 0.44^{\mathrm{bc}}$ & $5.20 \pm 0.33^{\mathrm{b}}$ & $5.20 \pm 0.18^{\mathrm{b}}$ & $5.10 \pm 0.34^{\mathrm{b}}$ \\
\hline $\mathrm{BS}_{\mathrm{U}}$ & $5.80 \pm 0.39^{\mathrm{bc}}$ & $5.80 \pm 0.33^{\mathrm{b}}$ & $5.70 \pm 0.31^{\mathrm{b}}$ & $5.90 \pm 0.53^{\mathrm{bc}}$ \\
\hline $\mathrm{S} \mathrm{S}_{\mathrm{U}}$ & $5.90 \pm 0.56^{\mathrm{b}}$ & $5.50 \pm 0.30^{\mathrm{b}}$ & $5.90 \pm 0.47^{\mathrm{b}}$ & $6.20 \pm 0.56^{\mathrm{b}}$ \\
\hline $\mathrm{NO}_{\mathrm{V}}$ & $5.60 \pm 0.26^{\mathrm{b}}$ & $4.90 \pm 0.31^{\mathrm{b}}$ & $4.60 \pm 0.40^{\mathrm{bc}}$ & $5.70 \pm 0.45^{\mathrm{bc}}$ \\
\hline $\mathrm{BO}_{\mathrm{V}}$ & $6.30 \pm 0.36^{\mathrm{b}}$ & $5.50 \pm 0.37^{\mathrm{b}}$ & $4.80 \pm 0.30^{\mathrm{bc}}$ & $6.70 \pm 0.51^{\mathrm{bc}}$ \\
\hline $\mathrm{SO}_{\mathrm{V}}$ & $6.50 \pm 0.58^{\mathrm{d}}$ & $5.10 \pm 0.55^{\mathrm{b}}$ & $6.40 \pm 0.53^{\mathrm{c}}$ & $6.80 \pm 0.58^{\mathrm{c}}$ \\
\hline $\mathrm{NF}_{\mathrm{R}}$ & $5.20 \pm 0.64^{\mathrm{bc}}$ & $6.00 \pm 0.49^{\mathrm{b}}$ & $7.20 \pm 0.41^{\mathrm{b}}$ & $6.10 \pm 0.68^{\mathrm{bc}}$ \\
\hline $\mathrm{BF}_{\mathrm{R}}$ & $7.90 \pm 0.31^{\mathrm{a}}$ & $7.30 \pm 0.30^{\mathrm{a}}$ & $7.80 \pm 0.32^{\mathrm{a}}$ & $7.80 \pm 0.32^{\mathrm{a}}$ \\
\hline $\mathrm{SF}_{\mathrm{R}}$ & $8.10 \pm 0.23^{\mathrm{a}}$ & $7.70 \pm 0.34^{\mathrm{a}}$ & $8.10 \pm 0.30^{\mathrm{a}}$ & $8.30 \pm 0.27^{\mathrm{a}}$ \\
\hline
\end{tabular}

Mean scores within the same column with different superscripts are significantly $(\mathrm{p}<0.05)$ different.

$\mathrm{NS}_{\mathrm{U}}=$ Non-pretreated sun-dried unripe plantain flour amala

$\mathrm{BS}_{\mathrm{U}}=$ Blanched sun-dried unripe plantain flour amala

$\mathrm{SS}_{\mathrm{U}}=$ Sulphited sun-dried unripe plantain flour amala

$\mathrm{NO}_{\mathrm{v}}=$ Non-pretreated oven-dried unripe plantain flour amala

$\mathrm{BO}_{\mathrm{v}}=$ Blanched oven-dried unripe plantain flour amala

$\mathrm{SO}_{\mathrm{V}}=$ Sulphited sun-dried unripe plantain flour amala

$\mathrm{NF}_{\mathrm{R}}=$ Non-pretreated freeze-dried unripe plantain flour amala

$\mathrm{BF}_{\mathrm{R}}=$ Blanched freeze-dried unripe plantain flour amala

$\mathrm{SF}_{\mathrm{R}}=$ Sulphited freeze-dried unripe plantain flour amala

The cooked dough (amala) prepared from the various unripe plantain flour (with and without pretreatment) generally had good sensory attributes as indicated by panellists' ratings (Table 5). Similarly, highest rating for colour, aroma, mouldability, consistency, mouthfeel and overall acceptability had been reported for unripe plantain amala compared to its moringa leaf powder fortified counterparts (Karim et al., 2015). Though both pretreatments (sulphiting and blanching) improved the sensory qualities, including colour, aroma and mouldability of the amala, only their interactive effect with freeze-drying was found to be significant $(\mathrm{p}<0.05)$. The cooked dough (amala) from freeze-dried unripe plantain flour samples had higher general acceptability ratings than those from sun and oven-dried samples. The highest dispersibility of sulphited freeze-dried unripe plantain flour may have contributed to the corresponding highest value of the general acceptability of the amala prepared from it.

\section{Conclusions}

Pretreatments and drying methods had varying individual and interactive effects on the proximate, mineral and functional properties of unripe plantain flour. Sulphiting and blanching enhanced the protein, fat, ash and moisture but reduced the crude fibre of the unripe plantain flour irrespective of drying methods. Moisture contents, except of sun-dried blanched plantain flour, were generally below the maximum level 
$(10 \%)$ recommended for safe keeping quality of flour. Though carbohydrates predominate the proximate compositions of the unripe plantain flour, protein, fat and ash contents were most retained in freeze-dried samples. The unripe plantain flour samples were all rich in calcium and phosphorus but low in sodium, which however, significantly increased with sulphiting. Blanching and sulphiting increased the phosphorus, iron and sodium but reduced the calcium content of the unripe plantain flour. Freeze-drying improved most of the functional properties of the flour and, blanching and sulphiting significantly increased the swelling power and dispersibility of freeze-dried unripe plantain flour. The stiff cooked dough (amala) prepared from all the plantain flour samples were favourably rated by the panellists, with sulphiting and blanching improving all sensory attributes. However, the cooked dough (amala) prepared from sulphited freeze-dried unripe plantain flour was the most generally accepted.

\section{References}

Adeniji, T.A., Sanni, L.O, Barimalaa, I.S., Hart, A.D. (2006). Determination of micronutrients and colour variability among new plantain and banana hybrids flours. World Journal of Chemistry, 1(1), 23-27.

Agoreyo, B.O., Akpiroroh, O., Oripke, O.A., Osawein, O.R., Owabor, C.N. (2011). The effects of various drying methods on the nutritional composition of Musa paradisiacal, Dioscorea rotundata and Colocasia esculent. Asian Journal of Biochemistry, 6(6), 458-464.

Akinyemi, S.O., Aiyelaagbe, I., Akyeampong, E. (2010). Plantain (Musa spp.) cultivation in nigeria: a review of its production, marketing and research in the last two decades. Acta Horticulturae, 879, 211-218.

Anderson, J.W., Baird, P., Davis, R.H.Jr, Ferreri, S., Knudtson, M., Koraym, A., Waters, V., Williams, C.L. (2009). Health benefits of dietary fiber. Nutrition Reviews, $67,188-205$.
AOAC. (2005). Official Methods of Analysis of the Association of Analytical Chemists International, 18th ed. (Official methods). AOAC International, Gathersburg, MD.

Arinola, S.O., Ogunbusola, E.M., Adebayo, S.F. (2016). Effect of drying methods on the chemical, pasting and functional properties of unripe plantain (Musa paradisiaca) flour. British Journal of Applied Science and Technolology, 14(3), 1-7.

Arisa, N.N, Adelakan, A.O., Alamu, A.E, Ogunfowora, E.J. (2013). The effect of pretreatment of plantain (Musa paradisiaca) flour on the pasting and sensory characteristics of biscuit. International Journal of Food and Nutritional Sciences, 2(1), 10-23.

Carbonaro, M., Mattera, M. (2001). Polyphenoloxidase activity and polyphenol levels in original and conventionally grown peach (Prunus persica L., cv. Regina bianca) and pear (Pyrus communis L., cv. williams). Food Chemistry, 72(4), 419424.

Chinma, C.E., Igbabul, B.D., Omotayo, O.O. (2012). Quality characteristics of cookies prepared from unripe plantain and defatted sesame flour blends. American Journal of Food Technology, 7(7), 398-408.

Dzomeku, B.M., Bam, R.K., Abu-Kwarteng, E., Ankomah, A.A. (2006). comparative study on the nutritional values of FHIA-21 (Tetratploid Hybrid) and apem (Triploid French Plantain in Ghana. Journal of Plant Sciences, 1(3), 187-191.

Emperatríz, P., Ronald, M., Elevina, P., Mily, S. (2008). Production and characterization of unripe plantain (Musa paradisiaca l.) flours. Interciencia, 33(4), 290-296.

Fadimu, G.J., Sanni, L.O., Adebowale, A., Kareem, S., Sobukola, O.P., Kajihausa, O., Abdulsam-Saghir, Siwoku, B., Akinsanya, A., Adenekan, M.K. (2018a). Effect of drying methods on the chemical composition, colour, functional and pasting properties of plantain (Musa parasidiaca) flour. Croatian Journal of Food 
Technology, Biotechnology and Nutrition, 13(1-2), 38-43.

Fadimu, G.J., Sanni, L.O., Adebowale, A.A., Kareem, S.O., Sobukola, O.P., Kajihausa, O.E., Abdulsam-Saghir, P., Siwoku, B.O., Akinsanya, A.O., Adenekan, M.K. (2018b). Optimisation of pre-treatment conditions for plantain (Musa parasidiaca) flour using Box-Behnken design. Quality Assurance and Safety of Crops \& Foods, 10(3), 223232.

Falade, K.O., Ogunwolu, O.S. (2012). Modelling of drying patterns of fresh and osmotically pretreated cooking banana and plantain slices. Journal of Food Processing and Preservation, 38, 373-388.

Falade, K.O., Olugbuyi, A.O. (2010). Effects of maturity and drying method on the physicochemical and reconstitution properties of plantain flour. International Journal of Food Science and Technology, 45, 170178.

Falade, K.O., Oyeyinka, S.A. (2015). Color, chemical and functional properties of plantain cultivars and cooking banana flour as affected by drying method and maturity. Journal of Food Processing and Preservation, 39(6), 816-828.

Gwanfogbe, P.N., Cherry, R.J., Simmon, J.G., James, S. (1988). Functionality and nutritive value of composite plantain (Musa paradisiaca) fruit and glandless cotton seed flours. Tropical Sciences, 28(1), 51-66.

James, C.S. (1995). Analytical chemistry of foods. Blackie Academic and Professional, London.

Karim, O., Kayode, R., Oyeyinka, S., Oyeyinka, A. (2015). Physicochemical properties of stiff dough "amala" prepared from plantain (Musa paradisca) flour and moringa (Moringa oleifera) leaf powder. Hrana u zdravlju $i$ bolesti, znanstvenostručni časopis za nutricionizam $i$ dijetetiku, 4(1), 48-58.

Karim, O.R. (2005). Effects of pre-treatments on the drying kinetics and quality attribute of air-dehydration of pineapple slices. PhD Thesis, Department of Food Science and
Technology, University of Agriculture, Abeokuta, Nigeria.

Karim, O.R. (2010). Effects of sulphiting and osmotic pre-treatments on the effective moisture diffusion coefficients deff of air drying of pineapple slices. African Journal of Food, Agriculture, Nutrition and Development, 10(10), 4168-4184

Karim, O.R., Kayode, R.M.O., Adeoye, O.S., Oyeyinka, A.T. (2013). Proximate, mineral and sensory qualities of 'amala' prepared from yam flour fortified with moringa leaf powder. Food Science and Quality Management, 12, 10-22.

Marriott, J., Lancaster, P.A. (1983). Bananas and Plantains. In: Handbook of Tropical Foods (Chan, J.H.T., Ed.). New York: Marcel Dekker Inc. pp. 85-145

Ndayambaje, J.P., Dusengemungu, L., Bahati, P. (2019). Nutritional composition of plantain flour of (Musa paradisiaca): the effect of various drying methods in Rwanda. American Journal of Food Science and Technology, 7(3), 99-103.

Ogazi, P.O. (1996). Plantain: production, processing and utilisation. Paman and Associates Ltd., Imo State, Nigeria, pp. 324.

Ogundare-Akanmu O.A., Inana, M.E., Adindu, M.N. (2012). Preliminary quality evaluation of selected plantain flour (Musa paradisiaca) sold in Port Harcourt markets, Nigeria. Food Science and Quality Management, 35, 7-10.

Ohizua, E.R., Adeola, A.A., Idowu, M.A., Sobukola, O.P., Afolabi, T.A., Ishola, R.O., Ayansina, S. O., Oyekale, T. O., Falomo, A. (2017). Nutrient composition, functional, and pasting properties of unripe cooking banana, pigeon pea, and sweetpotato flour blends. Food Science and Nutrition, 5, 750-762.

Ojure, M. A., Quadri, J.A. (2012). Quality evaluation of noodles produced from unripe plantain flour using xanthan gum. International Journal of Recent Research and Applied Studies, 13(3), 740-752 
Olawuni, I., Abimbola, U., Mejeha, I.M., Moses, O. (2013). Physio-chemical properties of plantain flour as affected by maturity, time and drying methods. Natural Products; An Indian Journal, 9(10), 386390.

Shofian, N.M., Hamid, A.A., Osman, A., Saari, N., Anwar, F., Dek, M.S.P., Hairuddin, M.R. (2011). Effect of freeze-drying on the antioxidant compounds and antioxidant activity of selected tropical fruits. International Journal of Molecular Sciences, 12(7), 4678-4692.

Yarkwan, B., Uvir, R.H. (2015). Effects of drying methods on the nutritional composition of unripe plantain flour. Food Science and Quality Management, 41, 5-10. Zakpaa, H.D. Mak-Mensah, E.E., Adubofour, J. (2010). Production and characterization of flour produced from ripe "apem" plantain (Musa sapientum L. var. paradisiacal; French horn) grown in Ghana. Journal of Agricultural Biotechnology and Sustainable Development, 2(6), 92-99. 